\title{
Dampak Implementasi Sistem Forlap Ristek Dikti bagi Perguruan Tinggi Telkom (Qualitative Approach)
}

\author{
Ade Rahmat Isk ${ }^{\# 1}$, Auliya Burhanuddin ${ }^{* 2}$, Adit Wijayanto ${ }^{\# 3}$ \\ \# Institut Teknologi Telkom Purwokerto \\ Jl. D.I. Panjaitan 128, Purwokerto, Indonesia \\ ${ }^{1}$ ade.rahmat@ittelkom-pwt.ac.id \\ 2 auliya@ittelkom-pwt.ac.id \\ ${ }^{3}$ aditya.wijayanto@ittelkom-pwt.ac.id
}

Accepted on September 28, 2018

\begin{abstract}
Penelitian ini dibuat untuk memberikan gambaran dampak dari diimplementasikannya Sistem Pangkalan Data Pendidikan Tinggi dalam istilah kebaruan forlap ristekditi di perguruan-perguruan tinggi Telkom. Penelitian ini dilakukan dengan metode literatur review dan qualitative approach. Qualitative approach dilaksanakan dengan menginterview para rektor perguruan tinggi Telkom di bawah Yayasan Pendidikan Tellkom berkaitan dengan dampak implementasi Sistem Pangkalan Data Pendidikan Tinggi; berdampak positif atau negatif dengan penggunaan teknologi online secara holistik. Literatur reiview terhadap kajian terhadap Datawarehouse dan era big data yang diterapkan oleh rsitek Dikti dalam mengelola semua data akademik di perguruan tinggi indonesia. Pendekatan qualitatif dilakukan dengan melakukan deep interview terhadap beberap manajemen atas perguruan tinggi telkom yaitu Institut Teknologi Telkom Purwokerto, Akademi Telkom Jakarta dan Telkom Unversity Bandung. Output dari penelitian adalah berupa penilaian point konversi nilai kuantitative berdasarkan Sodano's perspective menjadi penilai kualitatif yang diukur secara objektif.
\end{abstract}

Keywords: Forlap RsitekDikti, Qualiative Approach, Sodano's perspective

\section{PENDAHULUAN}

$\mathbf{S}^{\mathrm{s}}$ Istem pangkalan data pendidikan tinggi (PDPT) sudah dirancangn sejak tahun 2009 yang lalu. Pada awalnya sistem PDPT dikenal dengan aplikasi EPSBED (Evaluasi Program Studi berbasis Evaluasi diri). Beberapa kelemahan yang dimiliki sistem informasi sebelumnya sangat merugikan terutama bagai para manajer atas di perguruan tinggi, beberapa kendala diantaranya adalah (perubahan sistem yang terjadi secara instan; aplikasi sebelum tahun 2008 dibangun menggunakan aplikasi yang masih berbasis Disk Operating System (DOS) yaitu menggunakan Cliper, setiap operator pengolah data perguruan tinggi swasta harus melakukan pengolahan data secara manual, selanjutnya diberikan secara manual ke koordinator perguruan 
tinggi swasta (KOPERTIS) masing-masing, permsalahan yang sering terjadi berdasarkan hasil penelitian penulis dan 'recommendation to implement Database of Higher Education based on Change Management Persepective[1], ditemukannya praktik poiltik uang dari oknum pegawai Kopertis untuk memudahkan proses pelaporan data perguruan tinggi ke pihak Kopertis supaya data tersebut dianggap valid, point yang lain adalah, setiap operator perguruan tinggi secara rutin harus mendatangi setiap Kopertis untuk memberikan data tersebut secara manual melalui Disket atau flaskDisk. Berdsarakan fakta tersebut, Dikti selaku manajerial tertinggi pengelola perguruan tinggi di Indonesia untuk seluruh perguruan tinggi Negeri dan Swasta sudah melakukan upaya untuk memberikan satu layanan terpadu yang dikenal dengan Sistem Pagkalan Data Pendidiktan Tinggi (PDPT), yang sekarang dikenal dengan nama forlap.ristekdikti.

\section{KAJIAN TERKAIT}

Datawarehouse dianggap merupakan salah satu sistem informasi untuk mengadopsi semua data akademik di perguruan tinggi-perguruan tinggi di indonesia. Data warehouse merupakan pusat data yang dibentuk dari hasil penggabungan dan pengolahan data dari beragam sumber data. Biasanya data warehouse digunakan untuk keperluan pelaporan dan analisi data. Data warehouse (DW) didefinisikan juga sebagai suatu proses dan pengelolaan dan retieval data secara terpusat, Ralph Kimbal menjelaskan bawah Datawarehouse tidak hanya mengambil data dari data operasional[2] tetapi terdapat proses yang lebih diantaranya pengelolaan data secara subjektif dan historical data yang ditekankan dalam sistem ini.

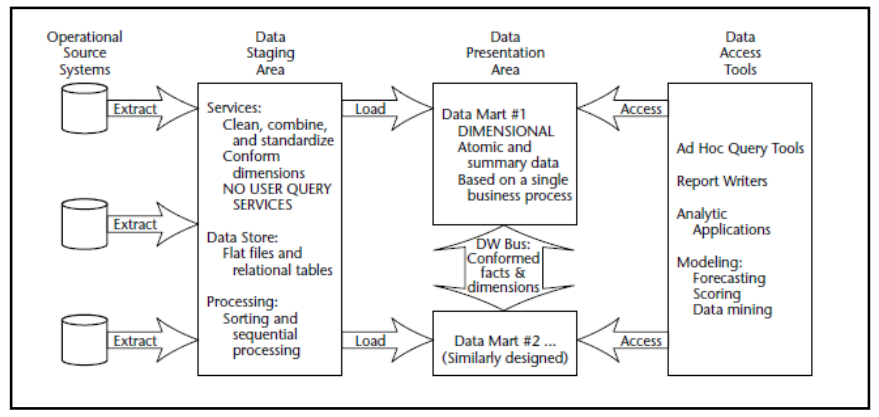

Gambar 1.1 Arsitektur Data warehouse[2]

Busines Intelligence (BI) merupakan kumpulan metodologi, proses, arsitektur dan teknologi yang berfungsi untuk mentransformasi data menjadi informasi yang berguna. Biasanya informasi ditampilkan dalam bentuk laporan, analitik, dan dashboard, pada umumnya Business Inteligence menggunakan Data Warehouse (DW) sebagai sumber datanya. Beberapa perbedaan dari Standar Database dan Data Warehouse adalah Standar Database (Mix atau update querying, MBs to GBs in size, thousand of users). Sedangkan datawarehouse memiliki beberapa karakteristik diantaranya yaitu (mostly reads infrequent updates, append-only-very rarely data is deleted, Query are complex and long-running, GBs to TBs in size).

A. Online Transaction Prcessing (OLTP)

Online Transaction Prcessing (OLTP) adalah teknologi untuk mengelola aplikasi yang berorientasi pada transaksi. Karena teknologi ini berhubungan dengan database, setiap database yang berhubungan dengan OLTP disebut database OLTP. Database OLTP adalah database yang umum digunakan pada aplikasi yang berorientasi transaksi, yaitu aplikasi yang cenderung lebih banyak melakukan proses insert, update dan delete secara real-time. Kelompok aplikasi berikut menggunakan database OLTP ( Enterprise Resource Planning, beberapa perangkat lunak ini diantaranya SAP ERP, Oracle JD Edwards EnterpriseOne dan JD Edwards World).

B. Online Analitical Porcessing (OLAP) 
Online Analitical Processing (OLAP) adalah teknologi untuk menjawab kebutuhan analitik. OLAP pun berhubungan dengan database. Database OLAP adalah database yang dimaksimalkan untuk kecepatan dalam pembacaan (select query). Salah satu sumber data untuk membentuk OLAP adalah database OLTP, OLAP dibentuk melalui proses Extract, transform dan Load (ETL). OLAP mengadung dua tipe dasar, yaitu (measures yaitu data bilangan yang terukur, misalkan kuantitas (quantity), harga(price), nilai rata-rata (averages), jumlah (sum) dari kelompok nilai tertentu, berikutnya adalah dimension yang mengacu pada kategori yang digunakan untuk mengatur measures. Biasanya data dikelompokan dalam bentuk bertingkat (level). Dimensi yang secara umum adalah dimensi waktu (time dimension), pada dimensi ini biasanya hierarkri disusun dari tahun, kuartal, bulan dan hari.

\section{Extract, Transform dan Load}

Pengelolaan data yang besar saat ini sangat diperlukan oleh beberapa perusahaan skala internasional, baik di instansi-instansi pemerintahan maupun di beberapa perusahaan-perusahaan yang mengelola data besar seperti Google, Facebook, LinkedIn dan lain-lain, pengelolaan data tersebut tidak berupa pengelolaan data transaksi tetapi sudah mengacu pada proses untuk pengelolaan data historical yang akan digunakan sebagai upaya untuk menganalisis data secara lebih jauh oleh perusahaan atau instansi tersebut.

Pengelolaan data akademik yang teritegrasi merupakan salah satu upaya untuk memudahkan dalam mengelola tiap sivitas akademika yang ada di Indonesia, dengan konsep regirtrasi tunggal seperti eKTP, begitu juga dengan Nomor Induk Dosen Nasional (NIDN) untuk para dosen yang ada di Indonesia dan Nomor Induk Mahasiswa (NIM) yang akan direkam secara permanent di database server forlapdikti.

Keterkaitan pengelolaan data besar dari transaksional tersebut dengan proses Extracting, Tansforming dan Loading atau lebih populer dikenal dengan nama ETL? Pada dasarnya pengelolaan database sudah trend sejak awal tahun 1960an silam, pengeloaan database biasanya bersifat transaksional untuk mengelola data dengan engan konsep create, update dan delete atau dikenal dengan istilah (CRUD) beberapa tipe sistem informasi dengan konsep transaksion processing system (TPS), sistem informasi manajemen (SIM) biasanya lebih sering dalam mengelola data dengan konsep transaksional, makanya seringkali pengelolaan database transaksional dikenal dengan istilah online transaksional processing (OLTP). Pada buku ini akan dipaparkan lebih mengacu pada pembahasan dari generasi database berikutnya yaitu data warehouse, dimana proses extracting, transforrming dan loading (ETL) terdapat pada saat transfromasi dari sumber-sumber data eksternal seperti dari database management system (DBMS) MysQL, SQ1 Server atau DBMS lainnya, flat files, xml atau pun sumber data lainnya kedalam database dengan konsep multidimensional modelling atau dikenal dengan istilah lain online analitical processing (OLAP).

\section{METODE PENELITIAN}

Metode penelitian yang dilakukan pada penelitan ini mengacu pada pendekatan Qualitative Approach. Penelitian dimulai dengan melakukan observasi di beberapa Perguruan Tinggi Telkom, yaitu Institut Teknologi Telkom Purwokerto, Telkom University dan Akademi Telkom Jakarta. Penelitian dilakukan dengan melakukan deep interview terhadap para principle dari perguruan tinggi telkom tersebut. Hasil dari interview dideksripsikan dalam tabel-tabel implementasi untuk dampak implementasi Sistem Pangkalan Data Pendidikan Tinggi (PDPT) dengan pendekatan manajerial dari Sodano yang diterbitkan dalam Fortune. Hasil qualitative dapat diberikan scoring dari hasil interview dan observasi tersebut dari terendah sampai tertinggi yaitu satu sampai tiga. 


\section{HASIL DAN PEMBAHASAN}

Mengacu pada penelitian sebelumnya, dalam rekomendasi implementasi Data warehouse of Higher Education System dengan Change Management[3]. Dapat diambil simpulan, bahwa kesiapan implementasi sistem tersebut dapat berjalan dengan normal. Implementasi sistem Forlap RistekDikti dapat mengintegrasikan Berikut adalah grafik perguruan tinggi berdsarkan aplikasi Sistem Pangakalan Data Pendidikan Tinggi (PDPT).

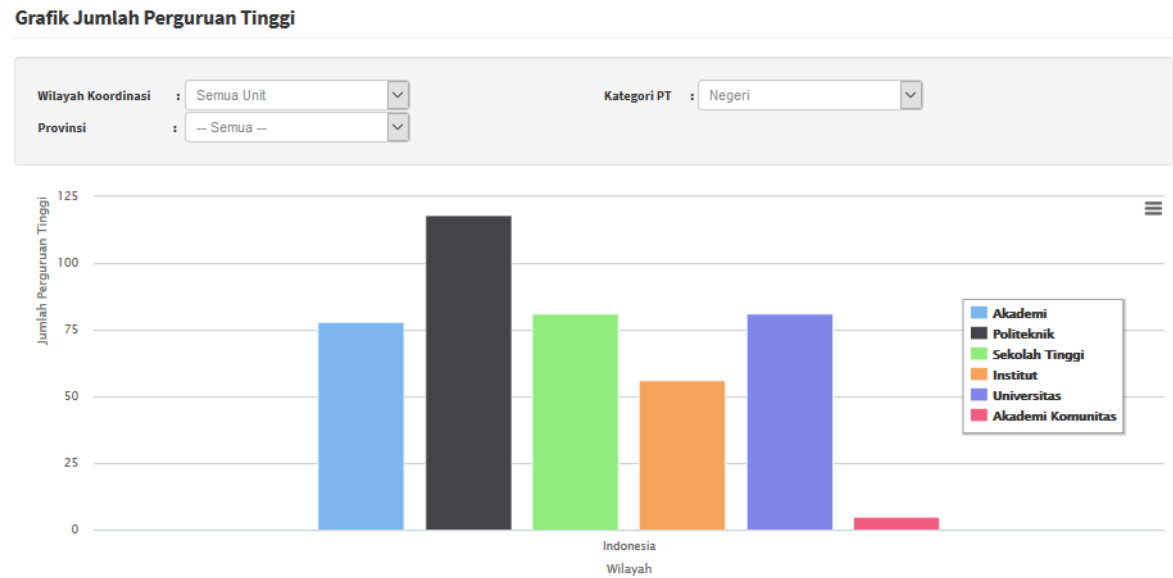

Gambar Jumlah Perguruan Tinggi, 2018

Sistem yang terintegrasi tersebut dapat diakses di laman https://forlap.ristekdikti.go.id/ . dari hasil penelitian yang dilakukan sebelumnya, sistem informasi forlap ristek dikti dapat mengintegrasikan semua perguruan tinggi yang ada di Indonesia baik perguruan tinggi negeri, maupun swasta, dengan jumlah program studi, dosen, mahasiswa yang dapat diakses secara realtime didalam satu portal datawarehouse tersebut. Perguruan tinggi Telkom (Institut Teknologi Telkom Purwokerto, Telkom University dan Akademi Telkom Jakarta). Institut Teknologi Telkom Purwokerto berada di lingkup Kopertis VI, Telkom University berada Kopertis IV dan Kopertis III untuk Akademi Telkom Jakarta. Langkah berikutnya setelah dilakukan observasi dan wawawncara dengan para decision maker di perguruan tinggi Telkom adalah, mengimplementasikan hasil interview kedalam tabel implementasi hasil interview yang berisi indikator-indikator pertanyaan yang diadopsi dari sodano's perpective. Berdasarkan Sodano's perspective diberikan penilaian dalam tingkatan (1: Buruk; 2: cukup baik; 3 : tinggi). Pada penelitian ini, hasil pembahasan diiplementasikan secara langsung pada tabel 1.1 berikut ini :

Tabel 1.1 Hasil Penelitian

\begin{tabular}{|l|l|l|}
\hline No & Category & Descriptive \\
\hline $\mathbf{1}$ & Sponsorship. & $\begin{array}{l}\text { Dalam fase ini, yang membuat perubahan adalah } \\
\text { manajer tingkat atas, bukan manajer operasional. } \\
\text { Orang yang memiliki arahan untuk mengkolaborasikan } \\
\text { kelompok perubahan ketika mereka menemukan. } \\
\text { Dalam fase penilaian ini, berikan tiga poin jika } \\
\text { dampak implemtasi Sistem Pangkalan Data Pendidikan } \\
\text { Tinggi (PDPT) mendapat dukungan lebih dari para } \\
\text { prinsiple Perguruan Tinggi dalam hal ini para rektor } \\
\text { dan Yayasan Pedidikan Tinggi Telkom. } \\
\text { Hasil penelitian: } \\
\text { Berdasarkan wawancara mendalam dengan para rektor }\end{array}$ \\
\hline
\end{tabular}




\begin{tabular}{|c|c|c|}
\hline & & $\begin{array}{l}\text { di perguruan tinggi telkom, dapat diberikan skor tiga } \\
\text { (3), dukungan untuk implementasi tatakelola teknologi } \\
\text { terhadap Sistem Pangkalan Data Pendidikan Tinggi } \\
\text { (PDPT) atau forlap RistekDikti sangat tinggi. Selain } \\
\text { itu, perguruan tinggi-perguruan tinggi di bawah } \\
\text { Yayasan Pendidikan Telkom memiliki beberapa sistem } \\
\text { informasi tersendiri untuk mendukung otomatisasi baik } \\
\text { dalam urusan akademik maupun administrasi seperti } \\
\text { iGracias (Integrated Akademic Information System) } \\
\text { yang sudah diimplementasikan di Telkom University } \\
\text { dan sekarang tahun } 2018 \text { diimplementasikan di Institut } \\
\text { Teknologi Telkom Purwokerto dan Akademi Telkom } \\
\text { Jakarta. }\end{array}$ \\
\hline 2 & Leadership. & $\begin{array}{l}\text { 1. Pada tahap ini, ini berarti kepemimpinan } \\
\text { operasional, orang yang menetapkan tujuan dan } \\
\text { memanggil rapat, dan mereka juga dapat bekerja } \\
\text { lembur. } \\
\text { 2. Harus diingat bahwa keberhasilan perubahan } \\
\text { biasanya jika para rektor berada pada level tinggi, } \\
\text { memiliki "kepemilikan", dan memiliki visi untuk } \\
\text { mengimplementasikan sistem akademik yang lebih } \\
\text { baik. } \\
\text { Hasil penelitian : } \\
\text { Secara umum kepemimpinan para rektor di perguruan } \\
\text { tinggi telkom memiliki leadership yang baik, hal ini } \\
\text { tidak lain karena YPT Telkom memberikan } \\
\text { kebebasan dalam pemilihan para rektor di perguruan } \\
\text { tinggi Telkom secara terbuka dengan proses yang } \\
\text { sistematis dengan mengacu pada standar yang berlaku } \\
\text { di Perguruan Tinggi Telkom. } \text { Dampak } \\
\text { diimplementasikan sistem forlap ristekDikti sangat } \\
\text { didukung dengan kepemimpinan para rektor yang pro } \\
\text { aktif terhadap implementasi sistem informasi tersebut; } \\
\text { dari hasil sub Leadership ini diberikan nilai tiga (3) } \\
\text { atau tinggi. }\end{array}$ \\
\hline 3 & Motivation. & $\begin{array}{l}\text { Terdapat dua kondisi pada bagian motivation. Berikan } \\
\text { poin bagus atau tinggi jika para rektor dan Yayasan } \\
\text { Perguruan Tinggi Telkom memiliki rasa urgensi yang } \\
\text { kuat, yang dimiliki oleh institusi, dan untuk budaya } \\
\text { institusi yang telah ditekankan untuk perbaikan } \\
\text { berkelanjutan. } \\
\text { Berikan skor rendah, jika beberapa manajemen atas } \\
\text { dan karyawan telah berada dalam posisi mereka lebih } \\
\text { dari lima belas tahun, dan mereka juga dalam budaya } \\
\text { konservatif yang tidak mau mengambil risiko. } \\
\text { Hasil penelitian: } \\
\text { Berdasarkan hasil wawancara dengan para rektor di }\end{array}$ \\
\hline
\end{tabular}




\begin{tabular}{|c|c|c|}
\hline & & $\begin{array}{l}\text { Perguruan Tinggi Telkom dan observasi di IT Telkom } \\
\text { Purwokerto; Akademi Telkom Jakarta dan Telkom } \\
\text { University. Para rektor dan yayasan pendidikan telkom } \\
\text { sangat mendukung upaya perbaikan berkelanjutan } \\
\text { secara sistematis dan memberikan jenjang karir yang } \\
\text { bersifat terbuka untuk para pegawai atau pun } \\
\text { Dosennya, kebijakan perpindahan suatu pegawain di } \\
\text { Perguruan Tinggi Telkom sangat dinamis dan dapat } \\
\text { terjadi dibawah lima tahun; poin (3) diberikan untuk } \\
\text { indikator motivasi ini. }\end{array}$ \\
\hline 4 & Direction. & $\begin{array}{l}\text { Pada fase ini, manajemen senior berpikir apakah dia } \\
\text { sangat yakin bahwa kondisi masa depan akan berbeda } \\
\text { dari sekarang, dan juga menanyakan bagaimana } \\
\text { gambaran manajemen yang jelas tentang masa depan, } \\
\text { dari implementasi sistem yang besifat fully online; } \\
\text { sistem forlap RistekDikti maupun aplikasi lain dari } \\
\text { tiap internal Kopertis (Kopertis III, IV dan VI). } \\
\text { Di sisi lain, manajer senior menganggap bahwa } \\
\text { manajer dapat merekrut semua dewan direksi, pihak } \\
\text { terkait, dan pelanggan untuk bertindak? Berikan tiga } \\
\text { atau poin tinggi untuk jawaban positif atas } \\
\text { pertanyaan-pertanyaan itu, jika para manajer senior } \\
\text { berpikir bahwa hanya sebagian perubahan yang } \\
\text { diperlukan, maka nilai indikator ini dengan poin } \\
\text { rendah. } \\
\text { Hasil penelitian: } \\
\text { Secara umum, instruksi yang telah dilakukan dapat } \\
\text { diberi skor tiga (3). Faktanya para rektor di perguruan } \\
\text { tinggi telkom dan Yayasan pendidikan telkom } \\
\text { bersikap futuristik, selalu memberikan arahan dalam } \\
\text { perancangan dan mengimplementasikan sistem-sistem } \\
\text { informasi terbarukan baik dari pemerintah maupun } \\
\text { dari lingkup yayasan pendidikan Telkom sendiri. }\end{array}$ \\
\hline 5 & Measurement & $\begin{array}{l}\text { Dalam fase ini, sudah dibentuknya tim penjaminan } \\
\text { kualifikasi. Berikan tiga poin jika ada indikator } \\
\text { kinerja seperti menggunakan metrik dan didorong } \\
\text { oleh manajemen secara total. } \\
\text { Yang kedua adalah, berikan dua poin atau skor } \\
\text { tengah, jika ada beberapa tindakan yang ada tetapi } \\
\text { sistem penghargaan dan kompensasi tidak diberikan } \\
\text { secara eksplisit. Yang terakhir adalah jika Anda tidak } \\
\text { tahu apa yang kami bicarakan atau tidak ada standar } \\
\text { pengukuran, buat skor sendiri untuk titik terendah. } \\
\text { Hasil penelitian : } \\
\text { Berdasarkan hasil wawancara dengan para rektor di } \\
\text { perguruan tinggi telkom dan Yayasan pendidikan } \\
\text { telkom dan hasil observasi yang dilakukan dapat } \\
\text { berikan poin tiga (3) karena pengukuran operasional } \\
\text { telah dilakukan secara baik (di perguruan tinggi } \\
\text { telkom sudah ada unit sendiri 'performansi' atau unit }\end{array}$ \\
\hline
\end{tabular}




\begin{tabular}{|c|c|c|}
\hline & & $\begin{array}{l}\text { Quality asurance yang mengukur kinerja dari } \\
\text { pencapai visi dan misi yang sudah didkelarasikan. }\end{array}$ \\
\hline 6 & $\begin{array}{l}\text { Organization } \\
\text { al Context }\end{array}$ & $\begin{array}{l}\text { Dalam fase ini, manajer perubahan harus } \\
\text { mengeksplorasi apakah upaya perubahan akan } \\
\text { berhubungan dengan hal-hal besar lainnya yang } \\
\text { terjadi di lembaga atau institusi tersebut? } \\
\text { Perubahan manajerial juga harus menganalisis apakah } \\
\text { sesuai dengan tindakan strategis atau sejalan dengan } \\
\text { produk baru? } \\
\text { Hasil penelitian: } \\
\text { Implementasi terintegrasi dengan forlap riskteDikti } \\
\text { dapat meningkatkan value dari efektifitas dan } \\
\text { efesiensi dalam pengelolaan data akademik dari tiap } \\
\text { perguruan tinggi terhadap RistekDikti begitu juga } \\
\text { sebaliknya. Semua perguruan tinggi tidak hanya } \\
\text { perguruan tinggi negeri dapat mengakses langsung } \\
\text { sistem forlap RestekDikti secara real time, berikan } \\
\text { nilai (3) dari hasil penelitian yang sudah dilakukan. }\end{array}$ \\
\hline 7 & $\begin{array}{l}\text { Processes/ } \\
\text { Functions. }\end{array}$ & $\begin{array}{l}\text { Proses atau fungsi harus dieksplorasi tentang } \\
\text { perubahan besar yang hampir selalu memerlukan } \\
\text { upaya besar untuk mendesain ulang proses bisnis } \\
\text { yang mungkin memerlukan pembiayaan tambahan. } \\
\text { Hal yang perlu dieksplorasi, jika proses-prosess atau } \\
\text { fungsional dikelola secara kaku, maka implementasi } \\
\text { perubahan sistem baru akan menjadi sulit. Anda dapat } \\
\text { memberikan poin yang tinggi jika mereka memiliki } \\
\text { dorongan yang kuat dari grup atau kelompok yang } \\
\text { solid meskipun mereka berpikir bahwa akan sulit } \\
\text { untuk menerapkan implementasi perubahan tersebut. } \\
\text { Hasil penelitian: } \\
\text { Secara umum, dampak implementasi sistem forlap } \\
\text { RistekDikti di perguruan tinggi telkom memberikan } \\
\text { perubahan proses yang signifikan; tetapi hal ini } \\
\text { sejalan dengan misi perguruan tinggi telkom yang } \\
\text { berorientasi pada digital kampus, hal ini direspon } \\
\text { dengan baik, seperti penyediaan infrastruktur dan } \\
\text { perangkat pendukung lainnya (telematika), faktor lain } \\
\text { untuk menjadi perguruan tinggi yang reliable, maka } \\
\text { poin tiga (3) diberikan secara layak pada indikator ini. }\end{array}$ \\
\hline 8 & $\begin{array}{l}\text { Costumer } \\
\text { focus. }\end{array}$ & $\begin{array}{l}\text { Pada tahap ini, harus dieksplorasi, bahwa semakin } \\
\text { banyak pegawai di insitusi dilibatkan dalam } \\
\text { brainstorming dengan pengetahuan dari customer, } \\
\text { dalam hal ini stakeholder perguruan tinggi adalah } \\
\text { (mahasiswa, orangtua mahasiswa, rekanan Perguruan } \\
\text { Tinggi dan pemerintah), dapat memberikan dampak } \\
\text { positif bahwa imlementasi sistem-sistem baru dapat } \\
\text { diterima dengan baik. } \\
\text { Hasil penelitian: } \\
\text { Pada tahap ini, penilaian diberikan tiga poin jika setiap } \\
\text { pegawai/sivitas akademika mengetahui siapa }\end{array}$ \\
\hline
\end{tabular}




\begin{tabular}{|l|l|l|}
\hline \multirow{3}{*}{} & $\begin{array}{l}\text { stakeholder mereka, berikan nilai kecil jika mereka } \\
\text { hanya hanya mengetahui para pegawai di unit tertentu } \\
\text { atau hanya mengetahui sebagian stakeholder saja. }\end{array}$ \\
& $\begin{array}{l}\text { Berdasarkan hasil penelitian, sivitas akademika di } \\
\text { perguruan tinggi telkom dan observasi, para pegawai di } \\
\text { perguruan tinggi telkom mengetahui siapa para } \\
\text { stakeholder mereka. Insittusi di perguruan tinggi } \\
\text { telkom sangat konsen terhadap value yang diharapkan } \\
\text { oleh para stakeholder. Nilai (3) diberikan untuk poin } \\
\text { costumerfocus ini. }\end{array}$ \\
\hline 9 & $\begin{array}{l}\text { Pada tahap ini, Anda dapat menilai skor tinggi, jika } \\
\text { tindakan matang dilakukan dengan cepat dengan } \\
\text { mempertimbangkan berbagai macam saran; tindakan } \\
\text { cepat diambil dengan pertimbangan yang matang. } \\
\text { Decision } \\
\text { Making. }\end{array}$ & $\begin{array}{l}\text { Sebaliknya, beri nilai rendah jika, keputusan yang } \\
\text { diambil tergesa-gesa dan tidak berdasarkan informasi } \\
\text { yang dapat dipertangggung jawabkan. } \\
\text { Hasil penelitian: } \\
\text { Secara umum, pengambilan keputusan yang diambil } \\
\text { oleh para manajer atas di perguruan tinggi telkom, } \\
\text { mengacu pada data dan informasi yang valid. } \\
\text { Berdasarkan pengamatan dan wawancara hampir } \\
\text { semua pegawai memahami dan mendukung keputusan } \\
\text { berbagai implementasi sistem informasi atau teknologi } \\
\text { baru, baik dari pemerintah, maupun dari pihak yayasan } \\
\text { pendidikan telkom (3). }\end{array}$ \\
\hline
\end{tabular}

\section{KESIMPULAN}

Dari hasil penelitian yang sudah dilakukan, dapat disimpulkan bahwa perguruan tinggi di bawah naungan Yayasan Pendidikan Telkom (Telkom University, Institut Teknologi Telkom Purwokerto, dan Akademi Telkom Jakarta) berdasarkan informasi yang diperoleh dari hasil wawancara secara mendalam dan observasi yang dilakukan di tiga perguruan tinggi Telkom tersebut memiliki dampak positif dari Implementasi Sistem Forlap RistekDikti terhadap tatakelola akademik di perguruan tinggi telkom tersebut. Total scoring mengacu pada tabel 1 adalah dua puluh tujuh (27) point dengan rata-rata penilaian adalah tiga (3) atau tinggi, hal ini mengindikasikan bahwa dampak implementasi sistem Forlap RistekDikti tersebut akan memberikan value advantage bagi perguruan tinggi di bawah pendidikan Telkom.

\section{ACKNOWLEDGMENT}

Terimakasih kepada Lembaga Penelitian dan Pengabdian Pada Masyarakat (LPPM) Institut Teknologi Telkom Purwokerto atas dana penelitan yang diberikan. Terimakasih kepada para manajer tingkat atas di Perguruan Tinggi Telkom (Rektor di Institut Teknologi Telkom Purwokerto, Telkom University, dan Direktur Akademi Telkom Jakarta). 
REFERENCES

[1] A. R. Iskandar, "Readiness For Implementing Data Warehouse of Higher Education System With Sodano 's Perspective," 2016.

[2] R. Kimball and M. Ross, The Datawarehouse Toolkit -The complete guide to dimention modeling. PAck ublisheing, 2010.

[3] A. R. Iskandar and K. Surendro, "Implementation of a Data Warehouse of Higher Education System at Kopertis West Java and Banten Based on Change Management," 2011. 